\title{
Creatio Continua and Quantum Randomness
}

\author{
Emil Salim and Shoaib Abmed Malik
}

\subsection{INTRODUCTION}

What does the doctrine of creation have to do with the issue of randomness? Orthodox Christian and Islamic traditions hold that God initially created the universe out of nothing. By itself, creation out of nothing doesn't dictate whether randomness exists or not in the universe. It is not God's act of creation that seems to be directly relevant to the existence of chance or fortune in the world, but God's governance.

Some schools of thought in the Christian and Islamic traditions, however, hold that God also continuously creates the universe after its initial creation out of nothing. In its most radical version, the doctrine says that God continuously recreates the universe out of nothing in each successive instant (Edwards 1970, 401-404). Although the doctrine of creation out

E. Salim $(\bowtie)$

Sekolah Tinggi Teologi Reformed Indonesia, Jakarta, Indonesia

e-mail: emil.salim@reformedindonesia.ac.id

S. A. Malik

Zayed University, Dubai, UAE

e-mail: Shoaib.Malik@zu.ac.ae

(C) The Author(s) 2022

243

K. J. Clark, J. Koperski (eds.), Abrahamic Reflections on

Randomness and Providence, https://doi.org/10.1007/978-3-030-75797-7_12 
of nothing (creatio ex nibilo) may not have a direct impact on the issue of randomness, the doctrine of continuous creation (creatio continua) surely does. ${ }^{1}$

This paper will discuss what we call The Common View of the doctrine of continuous creation that we offer as a common denominator between the Christian and Islamic traditions. ${ }^{2}$ It will also discuss whether there is a place for ontological quantum randomness in the universe if the doctrine of continuous creation is true. Ontological randomness is different from epistemic randomness. The latter has to do with human cognition and its limitations. Events appear to be random because our minds do not have the necessary information to understand why things happen the way they do. By contrast, ontological randomness is independent of human cognition, but concerns the causal nexus of entities that is deprived of efficient or final causation. In this paper, we argue that The Common View of the doctrine of continuous creation would preclude ontological randomness.

For clarity, let's first distinguish two interpretations of the doctrine of continuous creation. First, "the doctrine of continuous creation qua recreation" $\left(\mathrm{CC}_{\mathrm{Rec}}\right)$ says that continuous creation is conceptually equivalent to continuous conservation, but interprets continuous creation as continuous recreation. In this interpretation, objects constantly go out of existence and come into being by God's continuous ex nibilo recreation. Second, "the doctrine of continuous creation qua sustenance" $\left(\mathrm{CC}_{\text {Sus }}\right)$ also says that continuous creation is conceptually equivalent with continuous conservation, although it rejects that objects continuously vanish and are being recreated by God. In $\mathrm{CC}_{\text {Sus }}$, continuous creation is merely continuous sustenance, without repeated ex nibilo creation. We also stipulate $\mathrm{CC}_{\mathrm{Rec} / \mathrm{Sus}}$ as a blanket term for "continuous creation," which can be specified further into $\mathrm{CC}_{\mathrm{Rec}}$ or $\mathrm{CC}_{\text {Sus }}$.

\footnotetext{
${ }^{1}$ Pannenberg suggests that the concept of divine providence has three aspects: conservation, concurrence, and government (Pannenberg 1988, 8-9). In some theological traditions, conservation is considered equivalent to continuous creation. For this reason, the doctrine of continuous creation is very relevant to the issues of randomness and providence.

${ }^{2}$ This paper will not discuss the steady-state theory of Bondi and Gold, which was discounted by the presentation of the cosmological microwave background radiation that favors the Big Bang theory. This theory is sometimes called the "continuous creation" theory (Bondi and Gold 1948; Karimi 2011). For a panentheist-idealist version of the doctrine of the continuous creation, which will not be considered here, see Schultz and D'AndreaWinslow 2017. Karl Svozil uses the term "creatio continua" to refer to "indeterministic" generation process that results in quantum randomness (Svozil 2016, 28). Svozil's usage of "creatio continua" is not how we understand the phrase in this paper.
} 
Definition 1.1 $\mathrm{CC}_{\mathrm{Rec}}{ }^{3}$ God continuously recreates everything ex nibilo in successive instant. Objects continuously come into being and go out of existence. Continuous creation is not simply continuous sustenance.

Definition 1.2 $\mathrm{CC}_{\text {Sus }}$ God continuously creates everything, but objects don't continuously come into being and go out of existence. Continuous creation is simply continuous sustenance and not $e x$ nibilo recreation of objects.

Definition 1.3 $\mathrm{CC}_{\mathrm{Rec} / \mathrm{Sus}}$ God continuously creates everything, but "continuous creation" can be interpreted as either continuous ex nibilo recreation $\left(\mathrm{CC}_{\mathrm{Rec}}\right)$ or merely continuous sustenance $\left(\mathrm{CC}_{\mathrm{Sus}}\right)$.

We also need to note that when we use the word "conservation" without further specific information, we utilize it as a general term without specifying it as conservation qua continuous recreation or conservation qua mere sustenance.

\subsection{The Christian Traditions}

The Christian tradition has a long history of the doctrine of continuous creation, especially during the medieval and early modern periods. The doctrine also finds a way into contemporary analytic philosophy of religion.

\subsubsection{Nicolas Malebranche}

Malebranche (1638-1715) argues that God's continuous creation ( $\mathrm{CC}_{\mathrm{Rec}}$ ) Sus) ranges over both (a) the existence and (b) the determinate properties of objects, including their spatiotemporal coordinates. His argument for (a), namely, for the continuous creation $\left(\mathrm{CC}_{\mathrm{Rec} / \mathrm{Sus}}\right)$ of objects, is the argument from dependence: since creatures are metaphysically dependent on their creator, there isn't a possible world in which creatures exist but their creator (per impossibile) no longer does.

\footnotetext{
${ }^{3}$ In Sect. 12.4, we will stipulate that $\mathrm{CC}_{\mathrm{Rec}}$ is identical to what we shall call "The EdwardsAsh'arite Thesis."
} 
For Malebranche, continuous creation $\left(\mathrm{CC}_{\mathrm{Rec} / \mathrm{Sus}}\right)$ ranges over the determinate properties of objects, such as their location. ${ }^{4}$ His argument is that because the universe and its complete features are immediately created by God in every successive instant, there couldn't be a previous (or a subsequent) time-slice in which the properties of an object can be determined by God other than in the very instant the universe is created (Miller $2011,5)$. Instead, the imparting of all of the objects' determinate properties must be done by God simultaneously with the objects' coming into being, that is, at the moment of creation. It is simply inconceivable, according to him, that a chair exists unless it exists "somewhere, either here or elsewhere" (Dialogues VII.VI). ${ }^{5}$

\subsubsection{René Descartes}

Descartes (1596-1650) is another author who believes in the doctrine of continuous creation $\left(\mathrm{CC}_{\mathrm{Rec} / \mathrm{Sus}}\right)$. The Cartesian argument for continuous creation $\left(\mathrm{CC}_{\mathrm{Rec} / \mathrm{Sus}}\right)$ is an argument from the impotence of the objects to persist on their own over time. In the Third Meditation, he argues that an extended body does not have the power to ensure its existence in a future time. Because time is divisible into countless parts which are completely independent of one another, there is simply no guarantee that an object at time $t_{1}$ can assure its existence at time $t_{2}$ where $t_{2}>t_{1}$. The existence of an object, then, must be caused by something external, "which as it were creates me afresh at this moment-that is, which preserves me" (Descartes 1984, 33). To continue existing, at every successive instant, objects must be recreated by God. Descartes concludes that conservation and creation are different only by virtue of a distinction of reason. Nevertheless, we do not have a way of deciding between the literal and non-literal reading of Descartes' aforementioned sentence. That is, we don't actually know whether Descartes embraces $\mathrm{CC}_{\mathrm{Rec}}$ or $\mathrm{CC}_{\text {Sus }}$.

\footnotetext{
${ }^{4}$ See Lee 2008, 557 and Pessin 2000, 420. As a side note, Pessin argues that Malebranche's version of continuous creation (which Pessin interprets as $\mathrm{CC}_{\text {Sus }}$ ) doesn't entail occasionalism because continuous creation $\left(\mathrm{CC}_{\mathrm{Sus}}\right)$ is consistent with God's having volitional incompleteness (432). Roughly speaking, occasionalism is the view that God is the only real efficient cause in the universe, while secondary causation is merely an occasion for God's causal activity.

${ }^{5}$ If Pessin is correct, then for Malebranche, all of God's volitions have particular content, including his will about the locations of each extended body (Pessin 2001, 86).
} 


\subsubsection{Jonathan Edwards}

Like Descartes, Edwards (1703-1758) believes that existences are ontically bound to a particular time and place. Because of this fact, Edwards strongly argues that things cannot cause their own existence at a later time. Hence their existence at a later time must be immediately caused by an external agent, namely, the Creator.

What is absent in Malebranche and unclear in Descartes, however, is Edwards' explicit thought that objects continuously come into being and vanish, only to be recreated by God with gradual changes. In other words, Edwards clearly endorses continuous creation qua recreation $\left(\mathrm{CC}_{\mathrm{Rec}}\right){ }^{6}$ Since created objects (sometimes called "nature") are impotent to sustain their own existence, God must literally recreate them at every successive instant in their entire life span. Moreover, God not only recreates their existence, but also their "properties, relations, and circumstances" (Edwards 1970, 403).

\subsection{The Islamic Traditions}

There are several groups and thinkers in the Islamic traditions ${ }^{7}$ but our focus will primarily be the Ash'arite school of thought because they famously offer a unique combination of occasionalism and atomism, both of which will be useful to think about our continuous creation model. We primarily discuss and utilize the works of al-Juwayni (1028-1085) and his student, al-Ghazāli (1058-1111), both of whom are well-known in the Ash'arite household. ${ }^{8}$ Each of them wrote treatises that explicate the

\footnotetext{
${ }^{6}$ Compare this view to McCann and Kvanvig's, which suggests that the doctrine of continuous creation doesn't need to mean that the universe always appears anew every moment at its existence (McCann and Kvanvig 1991, 590). McCann and Kvanvig, however, still think that God determines both essential and accidental properties of objects (597). Another Christian historical figure other than Edwards who believes in the literal, "strong" view of continuous recreation of bodies $\left(\mathrm{CC}_{\mathrm{Rec}}\right)$ is Leibniz's contemporary Pierre Bayle (Anfray 2019). One can also find a similar view in the early Leibniz's doctrine of transcreation (White 2000).

${ }^{7}$ For excellent references on the various schools, see Wolfson 1976; Jackson 2014; Taftazani 1950; Muhtaroglu 2017; Frank 1966.

${ }^{8} \mathrm{~A}$ caveat needs to be pointed out. In the contemporary literature there is a healthy debate over Al-Ghazālī's metaphysical worldview. Some maintain, as we do provisionally in this article, that Al-Ghazālī was an Ash'arite, while others argue he was a covert Neoplatonist. To familiarize oneself with the advocates and references for either side, see footnote 8 in Malik 2019.
} 
Ash'arite doctrine. Al-Juwayni wrote A Guide to Conclusive Proofs for the Principles of Belief (Al-Juwayni 2000) and al-Ghazālī wrote Moderation in Belief (Al-Ghazālī 2013).

\subsubsection{The Ash'arite Worldview}

The initial bifurcation in their worldview is between Creator and the world, that is, anything other than God, where the former is a necessary being and the latter being entirely (and radically) contingent. The Ash'arites provide a systematic taxonomy on the metaphysics of the world. First, the world is divided into atoms ( jawhar ${ }^{9}$ ) and modes ( 'arad). Atoms are indivisible, self-subsisting, space-occupying (mutahayyiz) units, while modes are properties that adhere in atoms. These properties include things like color, taste, odor, life, and death. ${ }^{10}$ Modes cannot exist on their own and they need a locus to manifest themselves, which is why they subsist in atoms. In effect, atoms are simply indivisible scaffolds, similar to building construction. When atoms aggregate into various combinations, they form a body (jism). ${ }^{11}$ Second, the Ash'arites classify four states or manners of being (akwan). These include (1) movement, for example, rotational or translational; (2) rest, where an entity remains in the same position for two or more moments of time; (3) combination or aggregation of atoms or bodies; and (4) separation of atoms and bodies (Al-Juwayni 2000, 11; Al-Ghazālī 2013, 27). ${ }^{12}$ This forms the basic ontology of the Ash'arites upon which everything else is built. ${ }^{13}$

\footnotetext{
${ }^{9}$ In the kalamic texts, the word "jawhar" is sometimes equally used to refer to the atom and a body.

${ }^{10}$ These may seem archaic, which they are. It seems that macroscopic properties have been imposed on the microscopic world, something which modern physics may not agree with. For example, textures of macroscopic entities can be rough, but atoms themselves aren't "rough." By contrast, atoms have various properties specific to them which aren't visible in the macroscopic world, e.g., spin, charm, and strangeness.

${ }^{11}$ There is a disagreement among the mutakallimun over how many atoms are needed to combine to make a body.

${ }^{12} \mathrm{Al}$-Ghazāli doesn't discuss the akwan the same way that al-Juwayni does, but he has a discussion about rest and motion in general. See al-Ghazālī 2000, 31-33.

${ }^{13}$ For more information on this paradigm, see Erasmus 2018, 53-63; Sabra 2009; and MacDonald 1927. One could ask where the soul, angels, and demons fit in this scheme since they aren't material entities. To our knowledge, neither Al-Juwayni nor al-Ghazālī explicitly addresses the concern.
} 


\subsubsection{Motivation and Justification}

There are two main reasons for why the Ash'arites hold such a worldview. For one, the Ash'arites are strongly opposed to anything that contradicts the laws of logic because God is bound by them, that is, God can do everything except the logically impossible. This is the full extent of God's capabilities (Al-Ghazālī 2000, 175).

This is important because it explains how and why the Ash'arites take atomism seriously. They hold atomism, or more broadly a discrete-based worldview, to avoid infinities in creation as they can lead to contradictions, and God cannot produce contradictions. A common example is the comparison of the seed and the mountain. If both these very different entities can be divided into smaller and smaller entities ad infinitum, it would result in an infinite regress, which would be illogical as it suggests that both the seed and the mountain have the same (infinite) parts (McGinnis 2018). Accordingly, there must be a limit to nature and a fundamental unit which forms the basic building blocks of the natural world. ${ }^{14}$ For similar reasons, they hold discrete interpretations of space and time (Arthur 2012; Bulğen 2018; Altaie 2016, 17).

On this point, al-Ghazā $\overline{1}$ outlines three problems with an actual infinity. The first issue he raises with actual infinity is that it can never end, so to say infinity has passed is conceptually problematic (al-Ghazā $2013,37)$. The second problem he raises is related to counting of celestial properties with the passage of time. If infinity has passed, then it makes no sense to say that a celestial body has rotated an even or odd number of times. In effect, counting in temporal terms would be useless (37). The third problem al-Ghazā $\overline{1}$ raises is, pace Cantor, the existence of different sizes of infinities (38). Given these issues with actual infinity "neither in space nor in time can there be an infinity of extension, nor an infinity of subdivision, nor an infinity of succession" (MacDonald 1927).

The second reason for holding atomism is that atoms are the linking point between the natural world and God's power. If the very basic entities are under the command of God, then by extension everything else is. ${ }^{15}$

\footnotetext{
${ }^{14}$ It is along these lines that al-Ghazālī makes a distinction between atom and mode. A mode cannot subsist in another mode because then otherwise that second mode will need another mode and so on to infinite regress. There must be a stopping point or a locus within which a mode resides, which is the subsisting atom (Al-Ghazālī 2013, 34).

${ }^{15}$ Unless and of course God designed a bottom-up kind of emergence.
} 
Though this isn't a tight logical argument, as God could still be in absolute control of everything in the absence of particles, it just goes to show how thoroughgoing the Ash'arites are in making sure that nothing escapes God's control. It should be stressed that occasionalism is a predominant theme among the Ash'arites. ${ }^{16}$ The reason for this is because they don't agree with autonomy or agency existing out of God's control as it is seen to be theologically problematic (Jackson 2014; Farfur 2010). Everything outside of God relies on Him while He relies on no one. Furthermore, God doesn't decide what to do from one moment to another. Rather, because God is outside of time and space, God has already "decided" past, present, and future in a single timeless act. So, God has already fully determined each moment's existential posits, properties, relations, and circumstances.

\subsubsection{Implications}

The Ash'arite worldview has two very interesting implications. First, if everything exists momentarily in discrete time, and if everything in creation is contingent, that is, it could have equally existed or not existed, there must be a necessary being that wills it into existence over nonexistence (murajjih) (and vice versa) at each moment in time (Al-Juwayni 2000, 12; Al-Ghazālī 2013, 42). ${ }^{17}$ So it's not just that that atoms and their modes are sustained from one moment to another, rather everything is brought into existence from nothing and then annihilated into nothing in the next one, that is, $\mathrm{CC}_{\mathrm{Rec}}$. Reality, then, is fundamentally ephemeral. This contrasts with mere conservationism $\left(\mathrm{CC}_{\text {Sus }}\right)$ in which God merely sustains existences while nature/creation has some independence (Moad 2018), and process theology in which God evolves alongside nature in manifesting the development of nature/creation (Ruzgar 2016). In short,

\footnotetext{
${ }^{16}$ Plantinga 2016 distinguishes between strong and weak occasionalism. Strong occasionalism is the position that nothing in creation has any real authentic causal efficacy, including human free will. Weak occasionalism is the position that everything has no causal efficacy except the human will. The former was occupied by the Ash'arites and Maturidites but the latter was occupied by Mutazilites. See Jackson 2014.

${ }^{17}$ The reason is that any dependent series of contingent creations must rely on a necessary being.
} 
Ash'arite metaphysics sees the entire universe being continuously recreated like the refresh rate on a computer screen. ${ }^{18}$

Second, nothing in the world is intrinsically necessary. Since God is literally recreating every atom and mode everywhere in each time-slice, it implies that that there are no internal potentialities to things. It is simply God's will that manifests reality moment by moment. That is why al-Ghazālì (and Ash'arites in general) famously denies any kind of inherent necessity in creation, be they in the form of passive powers (Al-Ghazāli $2000,170)$ or active ones (166). That said, according to the Ash'arites God has chosen to manifest certain nomological laws in place (sunnatAllab), but there is nothing refraining Him from changing those laws if $\mathrm{He}$ chose to do so for the sake of performing miracles. So it is not impossible for God to convert a staff to a snake or split the seas or perform any other kind of nomological changes since they are all under the realm of logical possibilities.

\subsection{The Common View}

Both the Christian and Islamic traditions provide resources for constructing "The Common View of the Continuous Creation," which consists of five theses:

1. The Conservation Thesis: God continually conserves the existence of created substances.

2. The Equivalence Thesis: God's conserving created substances is equivalent to the continuous creation $\left(\mathrm{CC}_{\mathrm{Rec} / \mathrm{Sus}}\right)$ of the universe.

3. The Edwards-Ash'arite Thesis $\left(\mathrm{CC}_{\mathrm{Rec}}\right)$ : Objects vanish and are recreated by God ex nihilo at every successive instant. ${ }^{19}$

${ }^{18}$ Here it should be noted that there was (and still is) a debate about whether it was the atom and the modes that were being recreated or just the modes. For example, Altaie (2016, 17), a contemporary scholar of physics and kalam, seems to suggest that atoms are recreated alongside modes. By contrast, Ibn 'Arabi, a famous and classical Sufi theologian, is quite against the idea of substances as discussed by the Ash'arites as pointed out by Koca (2017). Regardless of what one makes of this debate, the key thing to remember here is that, at the very least, modes cannot endure more than a moment and are recreated. Interestingly, Adi Setia 2006, a contemporary scholar of Islamic intellectual thought, provides an explanation of this in that the atomism of the mutakallimun cannot but be thought of as a conceptual limit.

${ }^{19}$ Kim calls this sort of divine causation "vertical determination." He then uses the phrase "Edwards's Dictum" to describe the incompatibility between God's causation and creaturely 
4. The Bottom-Up Thesis: God's creation of objects includes the creation of all of the objects' properties or modes.

5. The Determinacy Thesis: God immediately wills the determinate properties or modes of objects.

We will now assess the consequences of this view for the issue of randomness.

\subsubsection{Conservation Without Determinacy}

It is possible to adopt The Conservation Thesis, but not The Determinacy Thesis. That is, it is possible to think that God conserves the world without determining every single property that created objects have. At most, The Conservation Thesis entails The Partial Determinacy Thesis, which says that some properties of an object $x$ are instantiated in virtue of $x$ 's existence being sustained. In the same way, one might think that God only conserves the existence of the world without determining all of the countless properties that created objects have.

\subsubsection{The Equivalence Thesis}

The Equivalence Thesis says that there is no difference between God's act of continuous creation $\left(\mathrm{CC}_{\mathrm{Rec} / \mathrm{Sus}}\right)$ and his act of continuous conservation. ${ }^{20}$ It is possible to adopt The Equivalence Thesis without embracing The Edwards-Ash'arite Thesis, and to claim that continuous creation is merely continuous sustenance, but not continuous recreation. This would result in $\mathrm{CC}_{\text {Sus }}$. Kvanvig and McCann, for example, think that there is equivalence between conservation and continuous creation. They claim that what is proposed in The Edwards-Ash'arite Thesis should be rejected, and suggest that the use of the word "creation" in the phrase "continuous creation" is a terminological infelicity (Kvanvig and McCann 2005, 15).

diachronic causation (Kim 2005, 36-39).

${ }^{20}$ Craig, however, insists that creation must be distinguished from conservation (Craig 1998). Accordingly, he would reject The Equivalence Thesis. 


\subsubsection{The Edwards-Ash'arite Thesis}

The Edwards-Ash'arite Thesis or $\mathrm{CC}_{\mathrm{Rec}}$ might run into problem on the assumption that God is timeless. If we agree with Malebranche that there is a single and undivided act of creation, in what sense does God continuously or repeatedly recreate $\left(\mathrm{CC}_{\mathrm{Rec}}\right)$ the world? Does The EdwardsAsh'arite Thesis require the assumption that God is actually in time instead of outside of time? If one assumes that God is in time, the doctrine of continuous creation $\left(\mathrm{CC}_{\mathrm{Rec}}\right)$ seems to be unproblematic. God can simply recreate the world in each time-slice. If God is timeless, however, the continuous recreation $\left(\mathrm{CC}_{\mathrm{Rec}}\right)$ of the world would have a different picture, perhaps one that includes space and time themselves to be a part of creation that constantly goes in and out of existence. At any rate, the problem about God's timelessness and its relation to God's creating act is not a problem unique for the doctrine of continuous creation $\left(\mathrm{CC}_{\mathrm{Rec}}\right)$, but for the doctrines of creation and divine action in general. Even if one doesn't subscribe to the doctrine of continuous recreation $\left(\mathrm{CC}_{\mathrm{Rec}}\right)$, one has to explain how a timeless God acts in the temporal world.

Another worry with The Edwards-Ash'arite Thesis is that it denies the persistence of objects and personal identity through time. The intuition is that an object never persists since at every moment it immediately vanishes. Quinn points out that this is problematic because if humans don't persist, they do not perform actions at all, which is contrary to both common sense and theistic orthodoxy (Quinn 1983, 63-67). One other significant worry here is that if there is no personal identity through time, then there is no conservation happening. If an object were to vanish, by definition, it would not have been conserved. If this were the case, then one couldn't equate continuous creation $\left(\mathrm{CC}_{\mathrm{Rec}}\right)$ with conservation.

The claim that the doctrine of continuous creation $\left(\mathrm{CC}_{\mathrm{Rec}}\right)$ precludes personal identity through time assumes either of the following premises. First, an object that has vanished cannot come into being again. Second, even if it could, it would not be identical to the vanished object. One way to address this issue is to adopt the exdurantist or stage theory view of persistence, in which objects persist in stages of short-lived entities (Haslanger 2003, 321). ${ }^{21}$ In exdurantism, objects persist in virtue of having counterparts in other temporal stages. In each stage of its life, the

${ }^{21}$ Crisp thinks that Edwards' metaphysics of persistence is either the stage view or fourdimensionalism with temporal parts (Crisp 2016, 202). However, Edwards actually denies that there is identity or oneness in the successive instants of recreated substances (Edwards 
object (i.e., a counterpart) is wholly present, although it comes into and goes out of existence at every successive instant. If identity requires that an object must continually exist through time, then exdurantism must bite the bullet and say that persistence doesn't require identity. As such, proponents of continuous creation $\left(\mathrm{CC}_{\mathrm{Rec}}\right)$ must say that although conservation requires persistence, it doesn't require identity.

However, instead of conceding that identity is absent in exdurantism, perhaps it is better to say that only a less robust notion of identity is required for persistence, which is a theory of identity that doesn't require seamless continuity in existence. Two analogies might be useful here. First, a film roll has many frames, which depict objects. The objects depicted in one frame are strictly speaking neither identical to nor spatiotemporally continuous with the objects depicted in another frame. When the film is played, however, viewers (and the exdurantists) see that objects persist and maintain personal identity over time. In this way, there is no robust ontological identity in objects, but only in the perception or the mind of the viewers. This view is sometimes called "the cinematographical view" of identity. ${ }^{22}$ Second, a patch of color persists through time but doesn't maintain identity due to the constant supply of photons needed. ${ }^{23}$ A person, upon seeing a color patch, can say that the color patch persists over time. In reality, nevertheless, the color patch is constantly refreshed as new photons enable it to be perceived. In these ways, exdurantism can maintain persistence with identity, although the notion of identity is less restrictive.

One immediate question that might arise here would be of moral responsibility. How are persons morally responsible if they persist without a robust sense of identity? The cinematic image would be helpful to invoke again. Human beings that are recreated continuously are morally responsible for their action to the extent that villainous film characters are in a sense responsible for their actions, although they are in reality a bundle of different film frames.

Admittedly, the philosophical problems discussed earlier are indeed difficult to address satisfactorily. The solutions require the acceptance of controversial intuitions about change, rigid designation, existential inertia,

1970, 403). This seems to point us toward the stage theory of objects. Crisp himself says in his later piece that for Edwards, objects exdure (Crisp 2018, 12).

${ }^{22}$ See Bergson 1911, 304-311 and Crisp 2016, 203-204.

${ }^{23}$ See Edwards 1970, 404 and Descartes 1984, 254-255. 
identity, and moral responsibility. However, we contend that seeing The Edwards-Ash'arite Thesis as a stage view can still be metaphysically defensible.

\subsubsection{The Bottom-Up and the Determinacy Theses}

The Bottom-Up Thesis says that God creates not only $x$, but also $x$ 's modes or properties. The Bottom-Up Thesis, however, is not explicit about whether God meticulously determines the properties of $x$. The Determinacy Thesis strengthens The Bottom-Up Thesis by asserting that God not only creates the properties of objects, but also meticulously determines them. On this view, theistic determinism thoroughly reigns in the world. Every property of objects is determined by God, including the properties of quantum particles.

\subsection{Continuous Creation and Quantum Mechanics}

The intersection of The Common View of the doctrine of continuous creation $\left(\mathrm{CC}_{\mathrm{Rec}}\right)$ and randomness includes the issue of the determinateness of properties. Suppose that God recreates the universe at every successive instant. Suppose that he also wills the determinate properties of each object, including its physical properties. How, then, would The Common View explain quantum weirdness in which particles sometimes are neither somewhere nor nowhere, but in a superposition? If The Common View is true, then the place of ontological randomness in the universe is questionable. Although there are two kinds of interpretations for quantum mechanics, namely, deterministic and indeterministic ones, in the following, we will only review the indeterministic Copenhagen interpretation.

Under the Copenhagen indeterministic interpretation of quantum mechanics, the wavefunction and its probabilistic character provide complete specification of a quantum state (Bohr 1935). ${ }^{24}$ On this view, however, one can't always say that a particle has a determinate location or momentum, particularly when it is in a superposition. According to Heisenberg's uncertainty principle, a system cannot simultaneously possess perfectly precise values of position and momentum. Heisenberg

\footnotetext{
${ }^{24}$ The term "Copenhagen interpretation" is used loosely here because we would associate not only Bohr with it, but also von Neumann.
} 
contends that there is something inherently indeterminate in the system. What is happening, then, when God recreates $\left(\mathrm{CC}_{\mathrm{Rec}}\right)$ the world at every successive instant, including when some particles are in a superposition?

Two metaphysical strategies are available here to maintain that God recreates $\left(\mathrm{CC}_{\mathrm{Rec}}\right)$ objects and properties. The first strategy is to see quantum properties as vague properties. Some philosophers think that there are problems in individuating macro-objects such as mountains and forests, for one doesn't always know where a mountain or a forest begins and where it ends. Sometimes there is no way to tell which trees can function as the exact boundaries of mountains and forests. The boundaries, in other words, are vague. Vagueness problem doesn't only plague objects, but also properties. Might quantum objects have vague properties? Lowe argues that quantum indeterminacy with respect to electrons is an example of real ontic vagueness in the properties of quantum objects such as positions and momenta (Lowe 1994, 114). Bokulich suggests that ontic vagueness in the properties of quantum particles obtains because they lack "space-time trajectories" and value definiteness in their positions, momenta, and so forth (Bokulich 2014, 463ff.). Unlike classical particles, quantum particles do not always have a determinate location, a definite spin, or an exact charge. This is especially true when they are in an entangled or superposed state. Perhaps some indeterminate quantum properties are vague properties and indeed display genuine ontic indeterminacy. ${ }^{25}$

The second strategy to maintain that God recreates $\left(\mathrm{CC}_{\mathrm{Rec}}\right)$ objects and properties in quantum events is to posit holism in the quantum states. Holism is the view that "a whole is something more than the sum of its parts, or has properties that cannot be understood in terms of the properties of the parts" (Maudlin 2013, 46). Perhaps quantum states are irreducible to any smaller parts. Unlike the first strategy, the recognition of holism doesn't require one to posit vague properties in the quantum state. Rather, the quantum state itself has properties that might be determinate, although the properties of its parts are themselves unspecifiable or even are lacking of a physical state (58). Juxtaposed with the doctrine of continuous creation $\left(\mathrm{CC}_{\mathrm{Rec}}\right)$, one can say that at some instants, particles become a part of a holistic quantum state. While no one could know for sure the nature of

${ }^{25} \mathrm{~A}$ metaphysical concept like vague properties might also be useful for the GhirardiRimini-Weber (GRW) interpretation of quantum mechanics, where during collapses, wavefunctions are not completely localized. See Monton 2000. 
quantum states, God would determine that some quantum states would contain a certain number of particles whose properties are not specifiable further. It is true that The Determinacy Thesis says that God wills that particles have determinate properties, but it doesn't follow from this that those determinate properties can be more determinate than being superposed in quantum state $Q$.

Adopting both the second strategy and The Common View might offer an explanation of how God acts in quantum events given the measurement problem in quantum mechanics. Von Neumann identifies that there are two processes by which quantum states evolve: the indeterministic and probabilistic process when a measurement occurs (Process 1) and the deterministic process in accordance with the Schrödinger wave equation (Process 2) (Neumann 1955, 417-418). In von Neumann's "orthodox" interpretation of quantum mechanics, the wavefunctions would "collapse" or "jump" during observations or measurements of particles, and the quantum states would undergo a process change from deterministic (Process 2) to indeterministic (Process 1) evolution. ${ }^{26}$ The measurement problem is a problem because one doesn't know how and when a wavefunction collapse would occur.

Let's situate the measurement problem within the current discourse of how "non-interventionist divine action"- assuming the necessitarian reading of the natural laws-plays a role in quantum events. Saunders lists the four possibilities of such divine action:

1. God alters the wavefunction between measurements.

2. God makes God's own measurements on a given system.

3 . God alters the probability of obtaining a particular result.

4. God controls the outcome of measurement. (Saunders 2002, 149ff.)

Saunders argues that these four possibilities are unsatisfactory because they require some kind of intervention on God's part (156). ${ }^{27}$

We argue that adopting The Common View and positing quantum holism can provide a better account of non-interventionist divine action in quantum events. To begin with, the strategy of positing quantum holism is not the same as altering wavefunction between measurements or

${ }^{26}$ The designation of Process 1 as indeterministic and Process 2 as deterministic follows Everett's exposition of the universal wavefunction in Everett 1973, 3.

${ }^{27}$ See different responses to Saunders' critique in Wildman 2008, 162ff. 
manipulating probability distributions (options 1 and 3). In contrast to option 1, God doesn't have to change the wavefunction to ensure that the outcome accord with his will. The reason is that in continuous creation $\left(\mathrm{CC}_{\mathrm{Rec}}\right)$, he can simply pick the initial quantum state to ensure it evolves into some later state via the Schrödinger equation (Process 2 ). In contrast to option 3 , accepting quantum holism is not claiming that God quirkily manipulates the probability distribution of a quantum state to achieve a certain outcome. In continuous creation $\left(\mathrm{CC}_{\mathrm{Rec}}\right)$, God only needs to create a certain holistic quantum state. Afterward, God will be able to determine the outcomes that fall within the probability distribution in the quantum state. The strategy is not the same as option 2 either because no measurements of the particle properties are made by God in the quantum state. Quantum holism concedes that some parts of the system are unspecifiable not because there is a lack of knowledge on anyone's part, but because of the very holistic character of the state.

Option 4 is only half-right. The strategy does say that God controls the outcomes of measurements because God creates the universe $\left(\mathrm{CC}_{\mathrm{Rec}}\right)$ at every successive instant. Saunders is worried about this option, saying that if it is taken, then we need to move ontologically backward, namely, from the outcomes of measurements to the determination of the ontological probability of the quantum state (Saunders 2002, 154-155). But The Common View can escape this worry. First, in God's continuous creation $\left(\mathrm{CC}_{\mathrm{Rec}}\right)$, the determination of the quantum state and its probability distribution at time $t_{1}$ is independent of the outcome at time $t_{2}$ where $t_{2}>t_{1}$. Second, the outcome is entirely according to God's determination and needn't violate any regular scientific laws because God can ensure that the outcome falls within the acceptable probability range (Tracy 2008, 273). God can work within the physical parameter such as wave amplitude that God himself has established.

The strategy of falling back metaphysically to quantum holism, then, fulfills Saunders' requirements for a reasonable "non-interventionist special divine action" that the quantum probabilities must:

1. be ontologically prior to the measurement and thus represent some feature of the system in question; and

2 . be modifiable by God without an intervention in the quantum wavefunction itself (which evolves deterministically under the Schrödinger equation). (Saunders 2002, 154) 
We argue that embracing The Common View and adopting quantum holism allow us to fulfill the first requirement, since in God's continuous creation $\left(\mathrm{CC}_{\mathrm{Rec}}\right)$, there is no need for a proleptic manipulation of the quantum wavefunction to match the outcomes. The probabilities can ontologically be determined before the measurements. The second requirement to modify probabilities is not applicable, since in continuous creation $\left(\mathrm{CC}_{\mathrm{Rec}}\right)$, God can determine the outcome of the measurements simply to be within the range of the logical probability distribution in the preceding quantum state. However, from the physicist point of view, there can still be epistemic randomness.

\subsection{ObJections and Replies}

One objection to our discussions would be to point out the obvious of the fact that the Christian and Muslim thinkers discussed in this paper lived before modern physics arrived. Why bother with juxtaposing the doctrine of continuous creation $\left(\mathrm{CC}_{\mathrm{Rec}}\right)$ with quantum randomness? Isn't this an anachronistic endeavor?

Indeed, The Determinacy Thesis was proposed by the thinkers before the quantum revolution. However, the theological position under scrutiny is still relevant, that God is the meticulous ruler of everything. It is important to show that traditional theological understanding can be reconciled with new sciences. While we appreciate that the sciences keep evolving, it is important to observe how theology stands in their light, as well as to ponder the theological implications of the new sciences (Vanney $2015,751)$.

Another objection would be to point out that our solution to reconciling continuous creation $\left(\mathrm{CC}_{\mathrm{Rec}}\right)$ with quantum randomness (under the standard interpretations) is simply to move the problem to a different metaphysical plane, namely, by saying that ontic quantum randomness is precluded because there are new metaphysical entities such as vague properties and holistic quantum states.

In response, we argue that both the notions of vague properties and quantum states are independent of the issue of randomness itself. Our task is to provide ways for reconciling the doctrine of continuous creation $\left(\mathrm{CC}_{\mathrm{Rec}}\right)$ with quantum randomness, which we have proposed already with these plausible metaphysical apparatus. It is also important to underline the fact that quantum states are weird and that the behaviors of particles 
might appear to be metaphysically beyond determinacy simply because they have an uncharted ontology.

A third objection might be that adopting quantum holism in which some properties such as spin, position, and momentum are momentarily inapplicable to particles is questionable. How is it the case that an electron at time $t_{1}$ has a position, but at time $t_{2}$ where $t_{2}>t_{1}$, when it is in a quantum state, locative properties can't be attributed to it?

To answer this objection, one should remember that the assertion about the inapplicability of properties such as spin and momentum to particles when they are in a quantum state is something of a common acceptance already in physics. It is simply a weird quantum phenomenon. However, perhaps we can persuade the reader to consider that there is a sense in which objects momentarily lose their property applicability. Imagine a ball that is vertically thrown up toward the sky. In the initial half of the trajectory it has a property of moving up. There is a point, that is, the vertex, however, when the ball will momentarily stop and lose the property of moving before it starts moving down due to its gravitational pull. There is nothing odd here. Also, the doctrine of the resurrection of the body might require that persons in the intermediate state do not have any spatial location while still existing. While these two analogies may not be satisfactory, they can be a starting point for further discussion.

\subsection{Conclusion}

Our paper finds common ground between orthodox Christian and Islamic thoughts on the doctrine of continuous creation $\left(\mathrm{CC}_{\mathrm{Rec}}\right)$. We reconcile the doctrine with the issue of quantum randomness and argue that if the doctrine is correct, there can't be ontic quantum randomness in this world. Under the standard indeterministic interpretations, the ontic quantum randomness is precluded if we buy into either the notion of vague properties or quantum holism, both of which are plausible metaphysical concepts to utilize. Lastly, we have also suggested that embracing The Common View of continuous creation $\left(\mathrm{CC}_{\mathrm{Rec}}\right)$ provides a way to show that a noninterventionist special divine action is possible in quantum events, for God would be able to determine both the wavefunction of quantum states and the outcomes of the measurement that fall within a reasonable probability range. ${ }^{28}$

\footnotetext{
${ }^{28}$ Our thanks go to Kelly Clark, Robert Koons, Jeffrey Koperski, Isra Yazicioglu, Karl Svozil, Michael White, and David Glick for commenting on an earlier draft of this paper.
} 


\section{BIBLIOGRAPHY}

Al-Ghazālī, Abu Hamid. 2000. Incoherence of the Philosophers. Translated by Michael E. Marmura. Utah: Brigham University Press.

- 2013. Moderation in Belief. Translated by Aladdin M. Yaqub. Chicago: The University of Chicago Press.

Al-Juwayni, Al-Haramayn. 2000. A Guide to Conclusive Proofs for the Principles of Belief. Translated by Paul E. Walker. Reading: Garnet Publishing.

Altaie, Basil. 2016. God, Nature, and the Cause: Essays on Islam and Science. Abu Dhabi: Kalam Research \& Media.

Anfray, Jean-Pascal. 2019. Continuous Creation, Occasionalism, and Persistence: Leibniz on Bayle. In Physics and Metaphysics in Descartes and in His Reception, Routledge Studies in Seventeenth-Century Philosophy, ed. Delphine AntoineMahut and Sophie Roux, 213-242. New York: Routledge.

Arthur, Richard T.W. 2012. Time Atomism and Ash'arite Origins for Cartesian Occasionalism Revisited. In Asia, Europe, and the Emergence of Modern Science, ed. A. Bala. New York: Palgrave Macmillan.

Bergson, Henry. 1911. Creative Evolution. Translated from the French by Arthur Mitchell. New York: Henry Holt \& Company.

Berkeley, George. 2008. Philosophical Writings,. ed. Desmond M. Clarke. Cambridge: Cambridge University Press.

Bohr, Nils. 1935. Can Quantum-Mechanical Description of Physical Reality Be Considered Complete? Physical Review 48: 696-702.

Bokulich, Alisa. 2014. Metaphysical Indeterminacy, Properties, and Quantum Theory. Res Philosophica 91 (3): 449-475.

Bondi, H., and T. Gold. 1948. The Steady-State Theory of the Expanding Universe. Royal Astronomical Society 108 (3): 252-270.

Bulğen, Mehmet. 2018. Continuous Re-creation: From Kalam Atomism to Contemporary Cosmology. Kalam 1: 60-66.

Craig, William L. 1998. Creation and Conservation Once More. Religious Studies 34 (2): 177-188.

Crisp, Oliver D. 2016. Jonathan Edwards and Occasionalism. In Abraham's Dice: Chance and Providence in the Monotheistic Traditions, ed. Karl W. Giberson, 195-212. Oxford: Oxford University Press.

- 2018. Jonathan Edwards on God's Relation to Creation. Jonathan Edward Studies 8 (1): 2-16.

Descartes, René. 1984. The Philosophical Writings of Descartes. Translated from the French by John Cottingham, Robert Stoothoff, and Dugald Murdoch. Vol. 2. Cambridge: Cambridge University Press.

Edwards, Jonathan. 1970. In Original Sin, Vol. 3 of The Works of Jonathan Edwards, ed. Clyde A. Holbrook. New Haven: Yale University Press. 
Erasmus, Jacobus. 2018. The Kalam Cosmological Argument: A Reassessment. Leiden: Springer.

Everett, Hugh, III. 1973. The Theory of the Universal Wave Function. In The Many-Worlds Interpretation of Quantum Mechanics: A Fundamental Exposition by Hugh Everett, III, with Papers by J. A. Wheeler, B. S. DeWitt, L. N. Cooper and D. Van Vechten, and N. Graham, Princeton Series in Physics, ed. Bryce S. DeWitt and Neill Graham, 3-140. Princeton: Princeton University Press.

Farfur, Muhammad Salih. 2010. The Beneficial Message and the Definitive Proof in the Study of Theology. Translated by Wesam Charkawi. London: Azhar Academy Ltd.

Frank, Richard. 1966. The Structure of Created Causality According to Al-Ash'ari. Studia Islamica 25: 13-75.

Haslanger, Sally. 2003. Persistence Through Time. In The Oxford Handbook of Metaphysics, ed. Michael J. Loux and Dean W. Zimmerman, 315-354. Oxford: Oxford University Press.

Jackson, Sherman. 2014. Islam and the Problem of Black Suffering. Oxford: Oxford University Press.

Karimi, Mirsaeid Mousavi. 2011. Adolf Grünbaum on the Steady-State Theory and Creatio Continua of Matter Out of Nothing. Zygon 46 (4): 857-871.

Kim, Jaegwon. 2005. Physicalism, or Something Near Enough. Princeton: Princeton University Press.

Koca, Ozgur. 2017. Ibn 'Arabi and the Ash'arites on Causality. In Occasionalism Revisited: New Essays from the Islamic and Western Philosophical Traditions, ed. Nazif Muhtaroglu, 41-60. Abu Dhabi: Kalam Research \& Media.

Kvanvig, Jonathan L., and Hugh J. McCann. 2005. Divine Conservation and the Persistence of the World. In Divine and Human Action: Essays in the Metaphysics of Theism, ed. Thomas V. Morris, 13-49. Ithaca: Cornell University Press.

Lee, Sukjae. 2008. Necessary Connections and Continuous Creation: Malebranche's Two Arguments for Occasionalism. Journal of the History of Philosophy 46 (4): 539-566.

Lowe, E.J. 1994. Vague Identity and Quantum Indeterminacy. Analysis 54 (2): 110-114.

MacDonald, Donald. 1927. Continuous Re-creation and Atomic Time in Moslem Scholastic Theology. Isis 30 (9): 6-28.

Malik, Shoaib. 2019. God, Information and the World: The Metaphysics of William Dembski and Al-Ghazali. Philosophy 94 (4): 547-576.

Maudlin, Tim. 2013. Part and Whole in Quantum Mechanics. In Interpreting Bodies: Classical and Quantum Objects in Modern Physics, ed. Elena Castellani, 46-60. Princeton: Princeton University Press.

McCann, Hugh J., and Jonathan L. Kvanvig. 1991. The Occasionalist Proselytizer: A Modified Catechism. Philosophical Perspectives 5: 587-615. 
McGinnis, Jon. 2018. Arabic and Islamic Natural Philosophy and Natural Science. In The Stanford Encyclopedia of Philosophy, ed. Edward N. Zalta. Metaphysics Research Lab, Stanford University. https://plato.stanford.edu/archives/ win2018/entries/arabic-islamic-natural/

Miller, Timothy D. 2011. Continuous Creation and Secondary Causation: The Threat of Occasionalism. Religious Studies 47: 3-22.

Moad, Edward Ryan. 2018. Divine Conservation, Concurrence, and Occasionalism. International Philosophical Quarterly 58 (2): 209-225.

Monton, Bradley. 2000. God Acts in the Quantum World. Oxford Studies in Philosophy of Religion 5: 167-184.

Muhtaroglu, Nazif. 2017. Al-Maturidi's View of Causality. In Occasionalism Revisited: New Essays from the Islamic and Western Philosophical Tradition, ed. Nazif Muhtaroglu. Abu Dhabi: Kalam Research \& Media.

Pannenberg, Wolfhart. 1988. The Doctrine of Creation and Modern Science. Zygon 23 (1): 3-21.

Pessin, Andrew. 2000. Does Continuous Creation Entail Occasionalism? Malebranche (and Descartes). Canadian Journal of Philosophy 30 (3): 413-439.

- 2001. Malebranche's Distinction Between General and Particular Volitions. Journal of the History of Philosophy 39 (1): 77-99.

Plantinga, Alvin. 2016. Law, Cause, and Occasionalism. In Reason and Faith: Themes from Richard Swinburne, ed. M. Bergmann and J.E. Brower, 126-144. Oxford: Oxford University Press.

Quinn, Philip L. 1983. Divine Conservation, Continuous Creation, and Human Action. In The Existence and Nature of God, University of Notre Dame Studies in Philosophy of Religion 3, ed. Alfred J. Freddoso, 55-80. Indiana: University of Notre Dame Press.

Ruzgar, M. 2016. Chance and Providence in the Islamic Tradition. In Abrabam's Dice: Chance and Providence in the Monotheistic Traditions, ed. Karl W. Giberson, 107-128. Oxford: Oxford University Press.

Sabra, A.I. 2009. The Simple Ontology of Kalam Atomism: An Outline. Early Science and Medicine 14: 68-78.

Saunders, Nicholas. 2002. Divine Action and Modern Science. Cambridge: Cambridge University Press.

Schultz, Walter J., and Lisanne D'Andrea-Winslow. 2017. Causation, Dispositions, and Physical Occasionalism. Zygon 52 (4): 962-983.

Setia, Adi. 2006. Atomism Versus Hylomorphism in the Kalam of al-Fakhr al-Din al-Razi. Islam and Science 4 (2): 113-140.

Svozil, Karl. 2016. Quantum Hocus-Pocus. Ethics in Science and Environmental Politics 16: 25-30.

Taftazani. 1950. A Commentary on the Creed of Islam. Translated by Earl Edgar. New York: Columbia University Press. 
Tracy, Thomas F. 2008. Particular Providence and the God of the Gaps. In Scientific Perspectives on Divine Action: Twenty Years of Challenge and Progress, ed. Robert John Russell, Nancey Murphy, and William R. Stoeger, 249-283. Vatican: Vatican Observatory.

Vanney, Claudia E. 2015. Is Quantum Indeterminism Real? Theological Implications. Zygon 50 (3): 736-756.

Von Neumann, John. 1955. Mathematical Foundations of Quantum Mechanics. Translated from the German by Robert T. Beyer. Princeton: Princeton University Press.

White, Michael J. 2000. The Foundations of the Calculus and the Conceptual Analysis of Motion: The Case of the Early Leibniz (1670-1676). Pacific Philosophical Quarterly 73 (4): 283-313.

Wildman, Wesley J. 2008. The Divine Action Project, 1988-2003. In Scientific Perspectives on Divine Action: Twenty Years of Challenge and Progress, ed. Robert John Russell, Nancey Murphy, and William R. Stoeger, 133-176. Vatican: Vatican Observatory.

Wolfson, Harry Austryn. 1976. The Philosophy of Kalam. Cambridge, MA: Harvard University Press.

Open Access This chapter is licensed under the terms of the Creative Commons Attribution 4.0 International License (http://creativecommons.org/licenses/ by $/ 4.0 /$ ), which permits use, sharing, adaptation, distribution and reproduction in any medium or format, as long as you give appropriate credit to the original author(s) and the source, provide a link to the Creative Commons licence and indicate if changes were made.

The images or other third party material in this chapter are included in the chapter's Creative Commons licence, unless indicated otherwise in a credit line to the material. If material is not included in the chapter's Creative Commons licence and your intended use is not permitted by statutory regulation or exceeds the permitted use, you will need to obtain permission directly from the copyright holder.

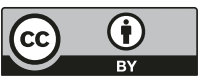

